Reprod. Nutr. Dévelop., 1988, 28 (6 B), 1599-1614.

\title{
Immunoregulatory cells in human decidua : morphology, immunohistochemistry and function
}

\author{
Judith N. BULMER ( ${ }^{1}$ ), Denise PACE, Anne RITSON \\ Department of Pathology, University of Leeds, \\ Leeds, LS2 9JT, U.K.
}

Summary. Suggestions that local intrauterine materno-fetal immune interactions may be important for normal pregnancy have led to investigation of immunoregulatory function by decidualised endometrium. Human decidua is complex and cell types may be difficult to distinguish at the light microscope level.

Immunohistochemical techniques have allowed antigenic identification of cells within decidua and abundant leucocytes are present throughout pregnancy. Macrophages $(\mathrm{CD} 14+)$ are abundant in decidua basalis and decidua parietalis throughout pregnancy and may be closely associated with extravillous trophoblast. Expression of class II MHC antigens and CD11c may suggest an immunological role but their content of lysosomal enzymes could indicate phagocytic functions. Antigen-presenting capacity has been noted in early human decidua and may be due to macrophages. Decidual macrophages have also been attributed with immunosuppressive function due to secretion of prostaglandin $E_{2}$. Decidual granulated lymphocytes are abundant in the first trimester and correspond to the so-called endometrial stromal granulocytes. They express CD2, CD7, CD38 and NKH1 but are negative for classical T cell and NK cell markers and they do not express the IL2 receptor. Semipurified populations show low levels of cytotoxicity in a standard NK assay. Thus, immunohistochemical techniques have allowed characterisation of potentially immunocompetent cells in human decidua. However, their roles both in vitro and in vivo remain to be established with certainty.

\section{Introduction.}

The decidualised endometrium lining the uterine cavity during normal human pregnancy has stimulated many morphological, biochemical, endocrinological and immunological studies. The inability to demonstrate any consistent alterations in maternal systemic immunity in normal pregnancy has recently led to suggestions that local intrauterine immunoregulatory mechanisms may be fundamental for survival of the semiallogeneic fetus, thus stimulating interest in possible immune functions of decidual tissue. Detailed light microscope studies of invasion of maternal uterine tissues by extravillous fetal trophoblast cells in a

(1) Correspondance to Dr. J. N. Bulmer. 
series of pregnancy hysterectomies (Pijnenborg et al., 1980) have also focussed attention on the complex materno-fetal inter-relationships within the placental bed which may be essential for normal pregnancy and fetal growth. Thus, decidualised endometrium is currently the subject of intense immunological interest.

\section{Morphology of human decidua.}

Human decidua may be subdivided according to its site : decidua basalis is in the area of the implantation site and forms part of the placental bed ; decidua parietalis (decidua vera) lines the uterine cavity away from the implantation area ; decidua capsularis is attached to the amniochorionic membranes and merges with decidua parietalis in later gestation as the uterine cavity is obliterated. The complexity of decidual tissue has been highlighted by light microscope and ultrastructural studies (Pijnenborg et al., 1980; Wynn, 1974; Tekelioglu-Uysal et al., 1975) but recent immunohistochemical studies have assisted in characterisation of the various cell types present.

In early pregnancy, endometrial stromal cells undergo morphological changes to form the large glycogen-rich decidual cell typical of this tissue. Similar predecidual changes may be seen premenstrually in the normal menstrual cycle and in pseudodecidua formed after progesterone treatment. Other cell types in decidua have been less well defined. Endometrial stromal granulocytes (EGs), also termed Körnchenzellen or " $K$ » cells, were recognised by Weill (1921) and have been described in non-pregnant and pregnant human endometrium by several others (von Numers, 1953; Hamperl \& Hellweg, 1958 ; Kazzaz, 1972 ; Dallenbach-Hellweg, 1981). EGs are abundant in decidua in the first trimester of pregnancy and in the late secretory phase of the menstrual cycle. They are characterised by variable numbers of phloxinophilic cytoplasmic granules and a small rounded, oval or indented hyperchromatic nucleus (fig. 1a). The granules also stain with eosin, toluidine blue, May-Grunwald Giemsa (MGG) and the periodic-acid-Schiff technique, amongst others (Bulmer, 1985). EGs are scattered throughout early pregnancy decidua but show some tendency to aggregate around spiral arteries and their branches and adjacent to endometrial glands. EGs can be well demonstrated in imprint preparations or early human decidua stained with toluidine blue (fig. 1b) or MGG but their granules appear to be lost by rapid snap freezing in liquid nitrogen. The origin of EGs has been controversial and for many years they have been presumed to derive from endometrial stromal cells and to secrete relaxin (Dallenbach-Hellweg, 1981). However, recent immunohistochemical studies (see below) have indicated that they are granulated lymphocytes (Bulmer et al., 1987a).

Macrophages also form a component of human decidua as do nongranulated lymphocytes. At the ultrastructural level, close association may be observed between decidual lymphocytes and macrophages and decidualised endometrial stromal cells, although the functional significance of such an association is not known (Tekelioglu-Uysal et al., 1975 ; Bulmer, 1985). Plasma 
cells are not normally seen in human decidua and immunohistochemical studies have failed to demonstrate immunoglobulin-containing plasma cells (Bulmer et al., 1986a).

In early pregnancy, trophoblast proliferates from the tips of the villi and spreads laterally to form the cytotrophoblast shell. Endovascular trophoblast then migrates in a retrograde direction up the uterine spiral arteries, replacing the endothelium. Interstitial trophoblast spreads through decidua basalis and the inner third of the myometrium, mononuclear cytotrophoblast often fusing to form multinucleate syncytial cells. The mechanisms of control of trophoblast proliferation and invasion are unknown. Extravillous trophoblast has been shown to express a novel class I MHC antigen which has a 40-41 kd heavy chain (Ellis et al., 1986) associated with $\beta_{2}$ microglobulin and a role of such an antigen in induction of local immunosuppression has been considered (Stern et al., 1986). However, the close association of maternal cells in decidua basalis with these extraembryonic fetal cells has raised the possibility that maternal cells within decidua may also play a role. Abnormal trophoblast invasion of uterine tissues and vessels has been reported in many pregnancy disorders, including pre-eclampsia (Khong et al., 1986), intrauterine growth retardation (Sheppard \& Bonnar, 1981), first trimester spontaneous abortion (Khong et al., 1987) and placenta accreta (Khong \& Robertson, 1987).

\section{Immunohistochemical studies of human decidua.}

The development of monoclonal antibodies and their application in single and double immunohistochemical labelling techniques has allowed characterisation of the various cell populations within human decidua and their interrelationships. Leucocytes (CD45+) from a major proportion of cells in human decidua throughout pregnancy (Bulmer \& Sunderland, 1983) and this observation has stimulated many functional studies. CD $45+$ cells are scattered throughout decidua but show some tendency to aggregate around vessels and glands (fig. 2a). Decidual leucocytes fall into two major groups characterised by their antigenic phenotype : macrophages, detectable throughout pregnancy (fig. 2b), and lymphocytes, which are observed mainly in first trimester decidua (fig. 3a). The leucocytic populations in decidua are summarised in Table 1 and those in non-pregnant endometrium in Table 2.

\section{Decidual macrophages.}

Macrophages have been detected in human decidua in early and late pregnancy tissues (Nehemiah et al., 1981 ; Bulmer \& Johnson, 1984 ; Kabawat et al., 1985a; Khong, 1987; Bulmer et al., 1988a, 1988b). They are present in decidua basalis and decidua parietalis and in the former, maternal macrophages are often intimately associated with extravillous fetal trophoblast (Bulmer et al., 1988b). Decidual macrophages may be identified by expression of CD14, detected by Leu-M3 and UCHM1, amongst others. They are generally unreactive for CD11b (OKM1) and CD15 (Leu-M1), both markers of blood monocytes. 


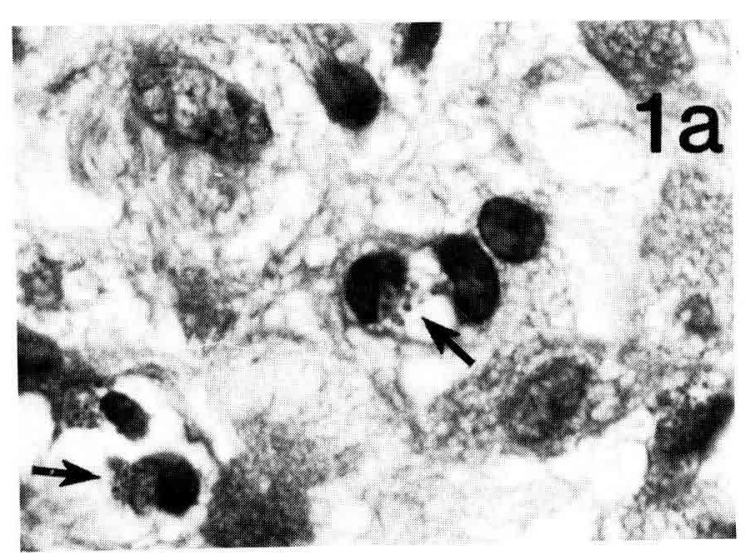

$f-z_{0} \div-7000$ $2 a v$ vo

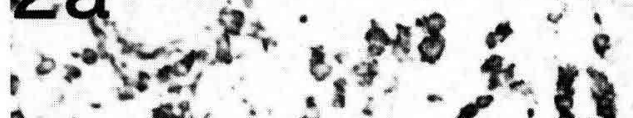
- $8 a^{2}$ - $70^{2}+0^{2} 0^{\circ} \%$

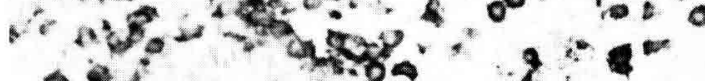

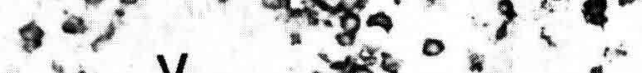

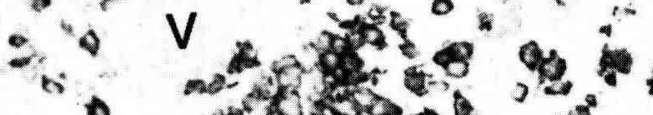

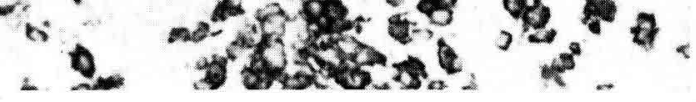

\section{$1 b$}

$2 b$ $\rightarrow \div$

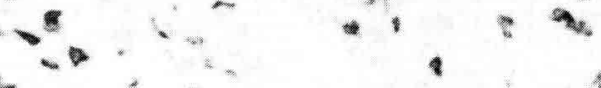

8

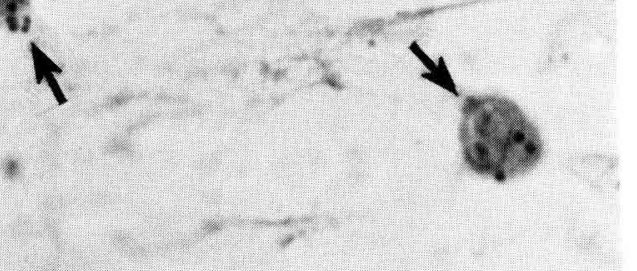

.530

18

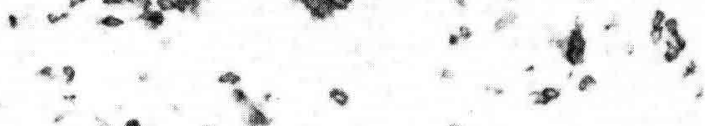

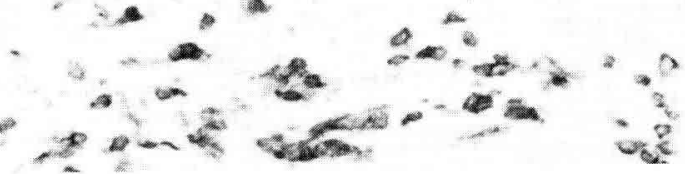

$3 a$ 4a a $\because 3 a+4 y^{2}+4$

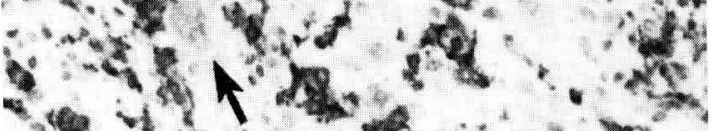
- v l

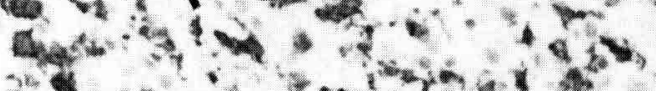
*1 2 his th

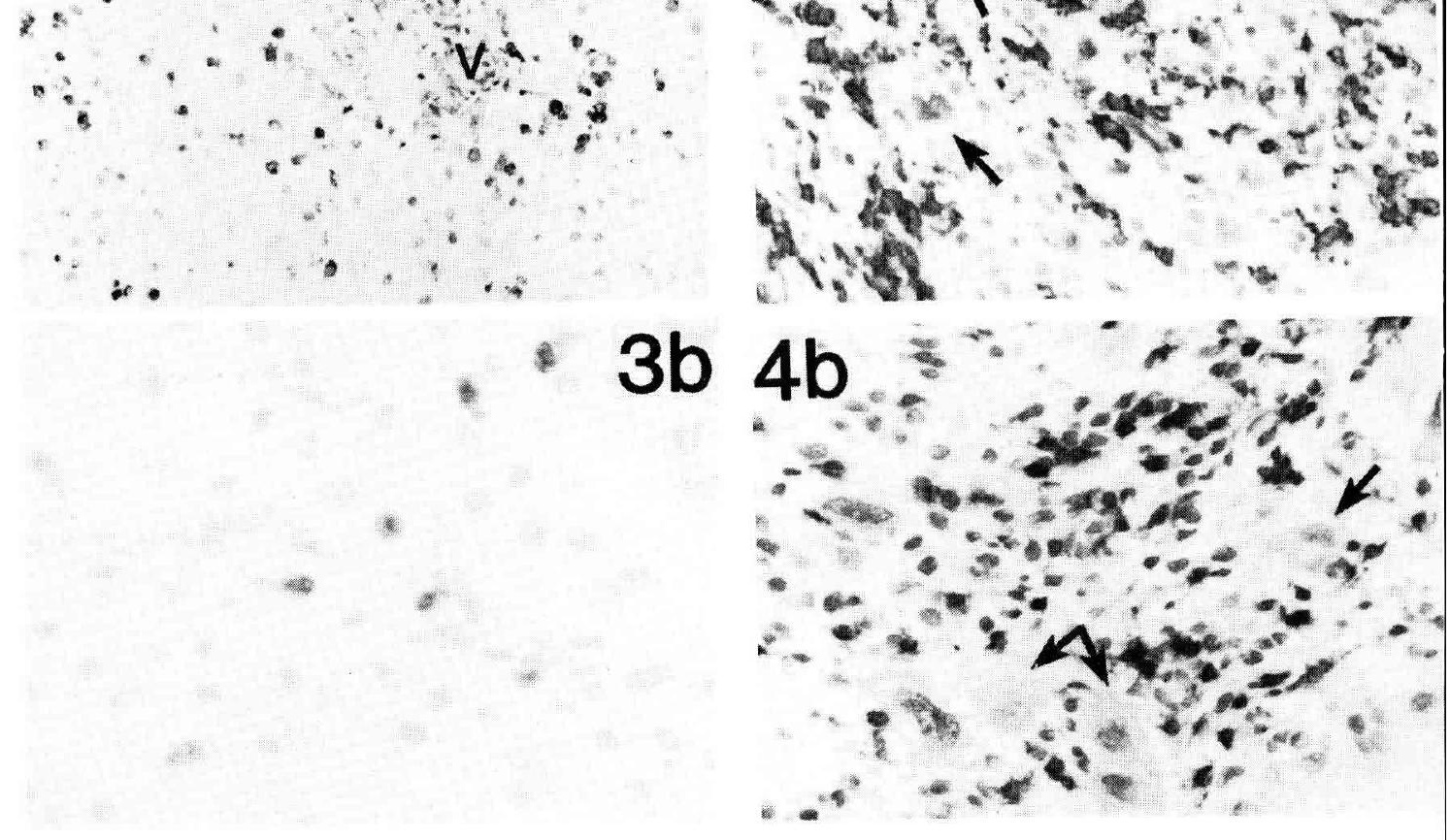


TABLE 1

Leucocytes in human decidua.

\begin{tabular}{lcc}
\hline & 1 st trimester & 3rd trimester \\
\hline Macrophages & +++ & +++ \\
B lymphocytes & \pm & \pm \\
T lymphocytes & + & + \\
CD2 + CD3 + & & + \\
Granulated lymphocytes & +++ & - \\
CD2 + CD3 - NKH1 + CD16- & & + \\
NK cells & - & \\
CD16 + NKH1 + leu7 + & &
\end{tabular}

TABLE 2

Leucocytes in non-pregnant human endometrium.

Stratum functionalis

\begin{tabular}{lccc} 
& Proliferative & ES & LS \\
\hline Macrophages & +++ & +++ & +++ \\
B lymphocytes & \pm & \pm & \pm \\
$\begin{array}{l}\text { T lymphocytes } \\
\text { CD2 + CD3 }+\end{array}$ & + & + & + \\
Granulated lymphocytes & & & +++ \\
CD2 + CD3 - NKH1 + CD16- & - & & - \\
NK cells & & - & \\
CD16+ NKH1 + leu7 + & - & & \\
\hline
\end{tabular}

FIG. 1. - Endometrial stromal granulocytes in first trimester human decidua (arrowed). (a) Paraffin section, phloxine tartrazine. (b) Imprint preparation, May Grunwald Giemsa.

Mag. $\times 900$.

FIG. 2. - First trimester human decidua label/ed for (a) CD45 to show abundant leucocytes particularly around vessels (V); (b) CD14 to show decidual macrophages.

Mag. (a) $\times 110$ (b) $\times 160$.

FIG. 3. - First trimester decidua labelled for (a) CD2 to show decidual granulated /ymphocytes ; (b) Ki67 to show that these lymphocytes proliferate within decidua.

Mag. (a) $\times 110$ (b) $\times 250$.

FIG. 4. - Decidua associated with total hydatidiform mole labelled with (a) DA6.231 (class II MHC) to show macrophages close to extravillous trophoblast cells (arrowed); (b) UCHT1 (CD3) to show aggregates of $T$ cells associated with extravillous molar trophoblast (arrowed).

Mag. (a) $\times 160$ (b) $\times 250$. 
The function of the large population of decidual macrophages is unknown. The majority express MHC class II and CD11c antigens (Bulmer et al.,1988a), which may be indicative of an immunological function. The close association of class II MHC + maternal macrophages with fetal trophoblast cells may also suggest an immune interaction. However, the majority of decidual macrophages contain acid phosphatase and non-specific esterase activity, detectable by enzyme histochemistry (Nehemiah et al., 1981 ; Bulmer \& Johnson, 1984), and $\alpha 1$ antitrypsin and $\alpha 1$ antichymotrypsin detectable by immunohistochemistry (Earl et al., 1988). Decidual macrophages are therefore well equipped to play a role in phagocytosis and scavenging of cell debris. Such a role may be important in removal of cells and tissue following trophoblast invasion. Macrophages may be detected in large numbers in the stroma of nonpregnant endometrium and their numbers show little variation with cycle stage (Bulmer et al., 1988c). Thus, the function of macrophages in decidualised endometrial stroma may be unrelated to pregnancy.

Several studies have attempted to determine the function of decidual macrophages in both human and murine decidua. Antigen-presenting capacity has been detected in first trimester human decidua and although this has not been attributed to a specific cell type it may be due to decidual macrophages (Oksenberg et al., 1986). Antigen-presenting capability has also been demonstrated in murine decidua and appears to be due to la-bearing macrophages (Searle, 1986). However, macrophages in decidua may also mediate immunosuppression. In murine decidua, macrophages have been shown to possess immunoregulatory activity due to secretion of prostaglandin $E_{2}$ (Tawfik et al., 1986). Similar findings have been reported for human decidua, although it has been suggested that decidualised endometrial stromal cells as well as macrophages secrete prostaglandin $\mathrm{E}_{2}$ (Lala et al., 1986).

A feature complicating many studies of decidual function is the difficulty in identifying cell types in cell suspensions by morphological criteria. Decidual macrophages, stromal cells and glandular epithelial cells may appear similar in dispersed preparations and criteria other than morphological ones are required for positive identification.

\section{Decidual lymphocytes.}

Lymphoid cells are present in decidua throughout pregnancy but are most prominent in the first trimester. Classical B lymphocytes are present in very small numbers in first trimester decidua but at term they may be observed around areas of necrosis or calcification in the decidua basalis (Bulmer \& Sunderland, 1984 ; Bulmer et al., 1988b). Classical T lymphocytes (CD2 +, CD3 +, CD5+) have been identified in small numbers in early and late pregnancy decidua and are scattered throughout decidua. Most are of the suppressor/cytotoxic CD8+ subset. CD4 has been detected on decidual macrophages and hence CD4+ helper T cells are difficult to identify with CD4 markers in immunohistological studies. 
In first trimester decidua an additional large lymphocytic population with an unusual phenotype has been identified. These cells are reactive for CD2, CD7 and CD38 (OKT10) but appear unreactive for CD3, CD4, CD5 and CD8 and for the interleukin 2 receptor (Bulmer \& Johnson, 1986). They do not express the classical natural killer (NK) cell markers Leu7 and Leu11 (CD16) but they are intensely rective with $\mathrm{NKH1}$ which labels large granulated lymphocytes including all natural killer cells (Bulmer \& Sunderland 1984; Ritson \& Bulmer, 1987a). These CD2 + CD3 - NKH1 + + lymphocytes form the major lymphoid population in early pregnancy decidua and are diffusely scattered throughout first trimester decidua with aggregates forming around spiral arteries and their branches and adjacent to endometrial glands (fig. 3a). They are uncommon in the second half of pregnancy. Similar CD2 + CD3 - NKH1 + lymphocytes have been identified in nonpregnant endometrium premenstrually particularly in areas of stroma which show predecidual change (Bulmer et al., 1988c). This distribution mirrors that of the endometrial stromal granulocytes. EGs lose their characteristic cytoplasmic granules on freezing but recent immunohistochemical studies of paraffin-embedded sections with monoclonal antibodies reactive on those tissues and of cells in suspension have provided convincing evidence that EGs are granulated lymphocytes (Bulmer et al., 1987a).

The presence of a large population of granulated lymphocytes in first trimester decidua raises questions regarding their function. Granulated lymphocytes (LGL) have generally been associated with NK and killer activity but decidual granulated lymphocytes do not possess classical NK cell markers. Lanier et al. (1986) have recently described a small subset of peripheral blood NK cells which lack CD16 but are intensely reactive with NKH1, a phenotype which matches that of decidual granulated lymphocytes. This peripheral blood NK cell subset was reported to be poor effectors in standard NK cell assays. A further population of LGL, termed natural suppressor (NS) cells, have been shown to mediate non-MHC specific immunosuppression (Maier et al., 1986).

The function of decidual granulated lymphocytes has been investigated with a variety of in vitro assays. Decidual tissue was obtained from first trimester pregnancy terminations and dispersed with collagenase type II (Ritson \& Bulmer, 1987b). Suspensions were enriched for granulated lymphocytes by density gradient centrifugation over a Nycodenz gradient and subjected to in vitro assays : 1) Proliferation in response to standard mitogens. 2) Suppression of peripheral blood lymphocyte mitogen responses by supernatants from cultures of decidual granulated lymphocytes. 3) Natural killer activity in a standard 4 hour K562 chromium release assay. For all assays, the activity of enriched decidual granulated lymphocytes was compared with that of unfractionated decidual cell suspensions.

After density gradient centrifugation decidual granulated lymphocytes (DGL) were enriched up to $80 \%$ in cell suspensions. DGL failed to proliferate in response to phytohaemagglutinin or concanavalin $A$; addition of high doses of interleukin 2 (IL2) failed to stimulate proliferation in these assays. Both unfractionated decidual cell suspensions and DGL produced significant suppression of peripheral blood lymphocyte mitogen responses. However, in all specimens, the level of 
suppression observed with unfractionated decidual suspensions was higher than that observed with DGL, thus suggesting that DGL were unlikely to be responsible for the bulk of immunosuppressive activity. However, DGL did consistently produce low but significant levels of cytotoxicity in a standard K562 chromium release assay. In all cases, DGL produced higher levels of killing than corresponding unfractionated decidual cell suspensions.

Thus, enriched populations of granulated lymphocytes from normal first trimester human decidua failed to produce immunosuppression above that seen in unfractionated decidual suspensions but did show low levels of cytotoxicity in an NK cell assay. The low level of effector activity may be analogous to that reported for the peripheral blood NK subset discussed above.

Further studies of more purified populations are required to further investigate proliferation and cytotoxicity of decidual granulated lymphocytes. However, the role of a cell with natural killer activity in decidua is an area for speculation. NK cells have recently been described in murine decidua (Croy et al., 1985) but their in vivo function is obscure. Granulated metrial gland (GMG) cells in the rat and mouse pregnant uterus have been considered to be analogous to human EGs and these have also been conclusively shown to be derived from bone marrow (Peel et al., 1983). GMG cells are particularly numerous in the labyrinth of the murine placenta and a functional interaction has been suggested (Stewart, 1984). Recent elegant video photographic studies of GMG cells within outgrowths co-cultured with labyrinthine trophoblast cells suggest that GMG cells may be directly cytotoxic to these trophoblast cells (Stewart \& Mukhtar, 1988). EGs/DGLs are prominent in human endometrium in secretory phase endometrium at the time of implantation and in early pregnancy when trophoblast invasion is established and it may be proposed that they play a role in control of trophoblast invasion by direct cytotoxicity. However, light microscope and electron microscope studies of human decidua have not provided any supporting evidence for such proposed cytotoxicity, although this may be a promising area for future ultrastructural studies.

\section{Kinetics of decidual lymphocytes.}

As already stated, macrophages may be detected in human endometrium throughout the menstrual cycle and at all stages of pregnancy. In contrast, lymphoid cells show considerable variation in numbers in nonpregnant and pregnant tissues (Bulmer et al., 1988d). B lymphocytes are uncommon in stratum functionalis throughout the cycle, although they may be seen within lymphoid aggregates in the basalis. Classical CD2 + CD3 + T lymphocytes are present in proliferative endometrium but increase in numbers in the early secretory phase. At least $75 \%$ of $T$ lymphocytes express CD8, a marker of the suppressor/cytotoxic subset. In late secretory phase tissues an additional population of CD2 + CD3 lymphocytes is observed and these are particularly prominent in areas of stroma which show predecidual change. The increase in CD2 + CD3 - lymphocytes corresponds to the detection of EGs in late secretory phase endometrial tissues. 
It is not known whether EGs (and therefore DGL) migrate into endometrium from the blood as fully differentiated cells or whether they differentiate in situ from precursor cells. EGs have been considered to be fully differentiated cells which are not seen in mitosis. However, we have recently been able to demonstrate mitotic activity in EGs, particularly in secretory phase tissues. Furthermore, the proliferation marker Ki67, which labels cells in all phases of the cell cycle excluding Go has been shown to be present in the nucleus of CD3 - CD2 $+\mathrm{NKH} 1++$ cells particularly in late secretory phase endometrium but also in early pregnancy decidua (fig. 3b). It appears, therefore, that EGs are capable of in situ proliferation within endometrium. No bone marrow or peripheral blood precursor cells of EGs have been identified. The aggregation of EGs around vessels was initially suggested to be due to diffusion of a factor, such as progesterone, stimulating differentiation of endometrial stromal cells at this site but it could also denote access of EGs to endometrium via blood. In studies of late secretory phase endometrium and early pregnancy decidua, EGs may be observed within the lumen of blood vessels. Changes in peripheral blood NK cells have been noted in pregnancy (Gregory et al., 1987) but there have been no studies of the CD16$\mathrm{NKH1}++$ subset described by Lanier et al. (1986). EGs in suspensions prepared from human decidua do not proliferate when progesterone is added to the culture medium. Furthermore, explants of proliferative endometrium which have been subjected to in vitro decidualisation by hormone manipulation of the culture medium do not contain the expected numbers of EGs within the decidualised stroma (Bulmer \& Longfellow, unpublished). Thus, although it is apparent that EGs do proliferate within endometrium, the mechanisms of induction and control of such proliferation remains obscure.

Hence, little information is currently available regarding the kinetics and differentiation of granulated lymphocytes in human endometrium. Detailed studies of NK cells in peripheral blood in the normal menstrual cycle and in pregnancy may provide useful data in this area but no factor has yet been found which is capable of stimulating EG differentiation or proliferation.

\section{Endometrial glands in human pregnancy.}

Endometrial glands have been reported to degenerate in early gestation, only isolated gland remnants being identified at light microscope level in the second half of pregnancy (Pijnenborg et al., 1980). In early pregnancy, endometrial glands appear to lose or decrease expression of $\mathrm{MHC}$ class I antigens (Johnson $\&$ Bulmer, 1984). The glands are also often surrounded by a dense mononuclear cell infiltrate which consists mainly of macrophages and granulated lymphocytes but also includes CD1 + cells, transferrin-receptor-bearing cells and class II $\mathrm{MHC}+\mathrm{T}$ lymphocytes (Bulmer \& Johnson, 1985). These two observations, namely of antigenic changes and an unusual mononuclear cell response, have suggested that the glands may be subject to immune destruction in early pregnancy. However, numerous glands have been demonstrated in third trimester placental bed tissues using antibodies reactive with epithelial cells, although the 
glands are often attenuated to form slit-like channels (Bulmer et al., 1986b). Despite this finding, the antigenic changes reported in pregnancy and the sharing of many trophoblast antigens by gland epithelial cells suggest that the glands are worthy of further investigation.

\section{Decidual leucocytes in abnormal pregnancy.}

Investigation of decidual leucocytes in pathological pregnancies may provide some insight into cell function. However, tissues are limited and often unsuitable for functional studies since they become available only after clinical presentation which may be delayed for several days after pregnancy failure.

In spontaneous abortion, decidua often shows large areas of necrosis and acute inflammation, and in these zones EGs are virtually absent. However, EGs may be seen in subjectively normal numbers in less inflamed areas. Nebel et al. (1986) noted dense infiltrates of lymphocytes in deep decidua and around blood vessels in abortions occurring 22-30 days following embryo transfer on an IVF-ET programme. Clark et al. (1987) examined decidua from patients undergoing spontaneous abortion and reported a deficiency of lymphocytes with large granules together with an excess of large lymphocytes with small cytoplasmic granules. However, the distinction of these cell types was not clear and further confirmatory studies are necessary.

In molar pregnancy trophoblast shows abnormal proliferation. Placental bed tissues in complete hydatidiform mole have been reported to contain a four-fold increase in number of classical CD3 $+T$ lymphocytes compared with decidua basalis in normal pregnancy and these are mostly CD8 + (Kabawat et al., 1985b) (fig. 4b). Macrophages are also abundant in molar pregnancy (fig. 4a); they are usually $\mathrm{MHC}$ class II + and are often closely associated with extravillous trophoblast cells. Endometrial stromal granulocytes may be identified by staining with phloxine tartrazine and in areas of decidualisation, CD2 + CD3 - lymphocytes corresponding to EGs can be identified (Bulmer et al., 1988d).

Ectopic pregnancy may provide clues to the function of leucocytes at the implantation site. When implantation occurs in the fallopian tube the pregnancy continues until haemorrhage, pain or tubal rupture necessitates surgical removal. Decidualisation at the tubal implantation site is often incomplete and patchy, although the endometrium usually shows decidualisation. The predominant leucocytes at the local implantation site in tubal pregnancy are class II $\mathrm{MHC}+$ macrophages which are often closely related to trophoblast. Classical CD2 + CD3 + T lymphocytes are also seen. In the absence of decidualisation EGs and CD2 + CD3 - lymphocytes are not present at the tubal implantation site. In contrast, intrauterine decidua contains numerous CD2 + CD3 - Iymphocytes and EGs as in normal pregnancy, as well as abundant macrophages (Earl et al.. 1987 ; Bulmer et al., 1987b). Thus EGs themselves may not be an essential local component of the implantation site although it is possible that they secrete a soluble factor capable of exerting its effect at a distant site.

Several observations have been proposed to support the concept that pregnancy-induced hypertension results from a disordered materno-fetal inte- 
raction. Physiological changes effected by endovascular trophoblast are absent in the myometrial segments of spiral arteries in this condition and in some spiral arteries are absent throughout their length. Khong (1987) noted no differences in quantity or type of decidual leucocytes between normal and pre-eclamptic pregnancies. However, studies were performed on third trimester tissues whereas any abnormal interaction between trophoblast and maternal cells in decidua is likely to occur much earlier in gestation.

\section{Immunosuppressive cells in decidua.}

Numerous investigations have been aimed at elucidating the nature of immunosuppressive cells in human and murine decidua. Supernatants from explants of early human decidual tissue suppress mitogen responses and mixed lymphocyte reactions (Golander et al., 1981 ; Nakayama et al., 1985) but the cell type (or types) responsible remains uncertain. Decidualised stromal cells from human decidua have been suggested to mediate immunosuppression by secretion of prostaglandin $E_{2}$ (Lala et al., 1986) : positive identification of decidual cells is, however, difficult and often relies on locally produced antibodies. Human decidual macrophages have also been shown to secrete prostaglandin $E_{2}$ and mediate immunosuppression (Lala et al., 1986). Daya et al. (1985) reported " large " and "small " suppressor cells in human decidua : their precise identity was not clear but it was suggested that they were lymphoid cells. Furthermore, glandular epithelial cells from nonpregnant endometrium have also been reported to have immunosuppressive function (Johnson et al., 1987).

Immunosuppression in murine decidua is also complex. True decidual cells in murine decidua have been suggested to derive from bone marrow and have suppressor activity mediated by secretion of prostaglandin $E_{2}$ (Lala et al., 1986). Macrophages in murine decidua have also been reported to secrete prostaglandin $\mathrm{E}_{2}$ which mediates immunosuppression (Tawfik et al., 1986). A small granulated non $T$ non $B$ lymphocyte which causes in vitro and in vivo suppression in murine decidua in the first half of pregnancy has also been extensively investigated (Clark et al., 1986). This lymphocyte apparently secretes a soluble factor which is capable of blocking $T$ lymphocyte responses to interleukin 2. Although this granulated lymphocyte bears $\mathrm{Fc}$ receptors it is distinct from the NK cell described by Croy et al. (1985) (Slapsys et al., 1986). This granulated lymphoid suppressor cell has been reported to be trophoblast dependent whilst trophoblast-independent suppressor cells have been reported in pseudodecidua (Clark et al., 1986).

Thus, immunosuppressive function has been attributed to numerous cell types in both human and murine decidua. The difficulty of establishing the identity of cells under investigation has caused problems in correlating results and the relative importance of the different "suppressor cells» in decidua is not known. Furthermore, although several cell populations may show immunosuppressive activity in vitro, their in vivo role has not been established: studies of abnormal tissues in human pregnancy may help to elucidate essential in vivo functions. 
Acknowledgements. - This work described was supported by Yorkshire Regional Health Authority and Birthright.

Résumé. Cellules immunorégulatrices de la déciduale humaine : morphologie, immunohistochimie et fonctions.

L'idée que les interactions immunologiques materno-fœtales au niveau de l'utérus puissent jouer un rôle important durant la gestation a conduit à rechercher les fonctions immunorégulatrices des cellules décidualisées de l'endomètre. La déciduale humaine est complexe et le type des cellules présentes est difficile à reconnaître en microscopie photonique. Les techniques immunohistochimiques ont permis l'identification antigénique des cellules de la déciduale et des leucocytes sont présents en abondance tout au long de la gestation (comparez tabl. 1 et 2). Les macrophages (CD14+) sont abondants dans la déciduale basale et la déciduale pariétale tout au long de la gestation et peuvent être étroitement associés avec le trophoblaste extravilleux (fig. 2). L'expression des antigènes $\mathrm{MHC}$ de classe Il et de CD11 c suggère un rôle immunologique possible, mais leur contenu en enzymes lysosomiales semble indiquer une fonction phagocytaire. La capacité à produire des antigènes, qui a été reconnue dans la déciduale humaine à un stade précoce, peut être due à la présence des macrophages. Une fonction immunosuppressive résultant de la sécrétion de prostaglandine E2 a été aussi attribuée à ces macrophages. Les cellules granuleuses lymphoïdes sont abondantes (fig. 3) dans la déciduale durant le premier trimestre et correspondent aux cellules dites granulocytes du stroma endométrial (fig. 1). Elles expriment CD2, CD7, CD38 et NKH1 mais sont négatives vis-à-vis des marqueurs des cellules T classiques ou des cellules tueuses, NKs (natural killers). Elles n'expriment pas le récepteur de IL2. Une population semi-purifiée montre un faible niveau de cytotoxicité dans un essai standard pour NK.

Ainsi les techniques histochimiques permettent une caractérisation des cellules potentiellement immunocompétentes dans la déciduale humaine. Cependant le rôle de ces cellules reste à déterminer avec certitude à la fois in vivo et in vitro.

\section{References}

BULMER J. N., SUNDERLAND C. A., 1983. Bone marrow origin of endometrial granulocytes in the early human placental bed. J. Reprod. Immunol., 5, 383-387.

BULMER J. N., JOHNSON P. M., 1984. Macrophage populations in the human placenta and amniochorion. Clin. exp. Immunol., 57, 393-403.

BULMER J. N., SUNDERLAND C. A., 1984. Immunohistological characterisation of lymphoid cell populations in the early human placental bed. Immunology, 52, 349-357.

BULMER J. N., 1985. Studies on the immunology of the human placenta in normal and pathological pregnancy. PhD Thesis, University of Bristol.

BULMER J. N., JOHNSON P. M., 1985. Immunohistological characterization of the decidual leucocytic infiltrate related to endometrial glands in early human pregnancy. Immunology, $55,35-44$.

BULMER J. N., JOHNSON P. M., 1986. The T-lymphocyte population in first-trimester human decidua does not express the interleukin-2 receptor. Immunology, 58, 685-687.

BULMER J. N., HAGIN S. V., BROWNE C. M., BILLINGTON W. D., 1986a. Localization of immunoglobulin-containing cells in human endometrium in the first trimester of pregnancy and throughout the menstrual cycle. Eur. J. Obstet. Gynecol. Reprod. Biol., 23, 31-44.

BULMER J. N., WELLS M., BHABRA K., JOHNSON P. M., 1986b. Immunohistological characterization of endometrial gland epithelium and extravillous fetal trophoblast in third trimester human placental bed tissues. Br. J. Obstet. Gynaecol., 93, 823-832. 
BULMER J. N., HOLLINGS D., RITSON A., 1987a. Immunocytochemical evidence that endometrial stromal granulocytes are granulated lymphocytes. J. Pathol., 153, 281-287.

BULMER J. N., RITSON A., EARL U., HOLLINGS D., 1987b. Immunocompetent cells in human decidua, 89-100. In CHAOUAT G. Reproductive immunology : materno-fetal relationship. Coll. Inserm, 154, Paris.

BULMER J. N., SMITH J. C., MORRISON L., 1988a. Expression of class II MHC gene products by macrophages in human uteroplacental tissues. Immunology, 63, 707-714.

BULMER J. N., SMITH J., MORRISON L., WELLS M., 1988b. Maternal and fetal cellular relationships in the human placental basal plate. Placenta, 9, 237-246.

BULMER J. N., LUNNY D. P., HAGIN S. V., 1988c. Immunohistochemical characterisation of stromal leucocytes in non-pregnant human endometrium. Am. $J$. Reprod. Immunol. Microbiol. 17, 83-90.

BULMER J. N., JOHNSON P. M., SASAGAWA M., TAKEUCHI S., 1988d. Immunohistochemical studies of fetal trophoblast and maternal decidua in hydatidiform mole and choriocarcinoma. Placenta, 9, 183-200.

CLARK D. A., SLAPSYS R., CHAPUT A., WALKER C., BRIERLEY J., DAYA S., ROSENTHAL K. L., 1986. Immunoregulatory molecules of trophoblast and decidual suppressor cell origin at the materno-fetal interface. Am. J. Reprod. Immunol. Microbiol., 10, 100-104.

CLARK D. A., MOWBRAY J., UNDERWOOD J., LIDELL H., 1987. Histopathologic alterations in the decidua in human spontaneous abortion : loss of cells with large cytoplasmic granules. Am. J. Reprod. Immunol. Microbiol., 13, 19-22.

CROY B. A., GAMBEL P., ROSSANT J., WEGMANN T. G., 1985. Characterization of murine decidual natural killer cells and their relevance to the success of pregnancy. Cel/. Immuno/., 93, 315-326.

DALLENBACH-HELLWEG G., 1981. The normal histology of the endometrium, 22-88. In Histopathology of the endometrium, Springer-Verlag, Berlin.

DAYA S., CLARK D. A., DEVLIN C., JARRELL J., CHAPUT A., 1985. Preliminary characterization of two types of suppressor cells in the human uterus. Fertil. Steril., 44, 778-785.

DAYA S., ROSENTHAL K. L., CLARK D. A., 1987. Immunosuppressor factor(s) produced by decidua-associated suppressor cells: A proposed mechanism for fetal survival. Am. $J$. Obstet. Gynecol., 156, 344-350.

EARL U., LUNNY D. P., BULMER J. N., 1987. Leucocyte populations in ectopic tubal pregnancy. J. clin. Pathol, 40, 901-905.

EARL U., MORRISON L., GRAY C., BULMER J. N., 1988. Proteinase and proteinase-inhibitor localization in the human placenta. Int. J. Gynaecol. Pathol. (in press).

ELLIS S. A., SARGENT I. L., REDMAN C. W. G., McMICHAEL A. J., 1986 . Evidence for a novel HLA antigen found on human extravillous trophoblast and a human choriocarcinoma cell line. Immunology, 59, 595-601.

GOLANDER G., ZAKUTH V., SHECHTER Y., SPIRER Z., 1981. Suppression of Iymphocyte reactivity in vitro by a soluble factor secreted by explants of human decidua. Eur. J. Immuno/., 11, 849-851

GREGORY C. D., LEE H., SCOTT I. V., GOLDING P. R., 1987. Phenotypic heterogeneity and recycling capacity of natural killer cells in normal human pregnancy. J. Reprod. Immunol., 11, 135-145

HAMPERL H., HELLWEG G., 1958. Granular endometrial stroma cells. Obstet. Gynecol., 11. 379-387.

JOHNSON P. M., BULMER J. N., 1984. Uterine gland epithelium in human pregnancy often lacks detectable maternal $\mathrm{MHC}$ antigens but does express fetal trophoblast antigens. J. Immunol., 132, 1608-1610.

JOHNSON P. M., RISK J. M., BULMER J. N., NIEWOLA Z., KIMBER I., 1987. Antigen expression at human maternofetal interfaces, 181-196. In GILL T. J. III, WEGGMAN T. G. «Immunoregulation and Fetal Survival ", Oxford University Press, New York.

KABAWAT S. E., MOSTOUFI-ZADEH M., BERKOWITZ R. S., DRISCOLL S. G., BHAN A. K., 1985a. Implantation site in normal pregnancy. A study with monoclonal antibodies. $A m$. $J$. Pathol., 118, 76-84. 
KABAWAT S. E., MOSTOUFI-ZADEH M., BERKOWITZ R. S., DRISCOLL S. G., GOLDSTEIN D. P., BHAN A. K., 1985b. Implantation site in complete molar pregnancy: a study of immunologically competent cells with monoclonal antibodies. Am. J. Obstet. Gynecol., 152, 97-99.

KAZZAZ B. A., 1972. Specific endometrial granular cells. A semi-quantitative study. Eur. J. Obstet. Gynecol., 3, 77-84

KHONG T. Y., DE WOLF F., ROBERTSON W. B., BROSENS I., 1986. Inadequate maternal vascular response to placentation in pregnancies complicated by pre-eclampsia and by small-forgestational age infants. Br. J. Obstet. Gynaecol., 93, 1049-1059.

KHONG T. Y., 1987. Immunohistologic study of the leukocytic infiltrate in maternal uterine tissues in normal and pre-eclamptic pregnancies at term. Am. J. Reprod. Immunol. Microbiol., 15, $1-8$.

KHONG T. Y., ROBERTSON W. B., 1987. Placenta creta and placenta praevia creta. Placenta, 8, 399-409.

KHONG T. Y., LIDDELL H. S., ROBERTSON W. B., 1987. Defective haemochorial placentation as a cause of miscarriage : a preliminary study. Br. J. Obstet. Gynaecol., 94, 649-655.

LALA P. K., PARHAR R. S., KEARNS M., JOHNSON S., SCODRAS J. M., 1986. Immunological aspects of the decidual response, 190-198. In CLARK D. A., CROY B. A. Reproductive immunology 1986, Elsevier Sci. Publ. B.V., Amsterdam.

LANIER L. L., LE A. M., CIVIN C. I., LOKEN M. R., PHILLIPS J. H., 1986. The relationship of CD16 (leu 11) and leu 19 (NKH1) antigen expression on human peripheral blood NK cells and cytotoxic T lymphocytes. J. Immunol., 136, 4480-4486.

MAIER T., HOLDA J. H., CLAMAN H. N., 1986. Natural suppressor (NS) cells : members of the LGL regulatory family. Immunol. Today, $7,312-315$.

NAKAYAMA E., ASANO S., KODO H., MIRRA S., 1985. Suppression of mixed lymphocyte reaction by cells of human first trimester pregnancy endometrium. J. Reprod. Immunol., 8, 25-31.

NEBEL L., FEIN A., RUDAK E., BLANK M., MASHIACH S., DOR J., LERRAN D., GOLDMAN B., 1986. Structural aspects of embryo failure following in vitro - fertilization and embryo transfer; immune rejection or malimplantation, 227-235. In CLARK D. A., CROY B.A. Reproductive immunology 1986, Elsevier Sci. Publ. B.V., Amsterdam.

NEHEMIAH J. L., SCHNITZER J. A., SCHULMAN H., NOVIKOFF A. B., 1981. Human chorionic trophoblasts, decidual cells and macrophages: a histochemical and electron microscopic study. Am. Obstet. Gynecol., 140, $261-268$.

OKSENBERG J.R., MOR YOSEF S., PERSITZ E., SCHENKER Y., MOZES E., BRAUTBAR C., 1986. Antigen presenting cells in human decidual tissue. Am. J. Reprod. Immunol. Microbiol., 11, 82-88.

PEEL S., STEWART I. J., BULMER D., 1983. Experimental evidence for the bone marrow origin of granulated metrial gland cells of the mouse uterus. Cell Tissue Res., 233, 647-656.

PIJNENBORG R., DIXON G., ROBERTSON W. B., BROSENS I., 1980. Trophoblast invasion of human decidua from 8-18 weeks of pregnancy. Placenta, 1, 3-18.

RITSON A., BULMER J. N., 1987a. Endometrial granulocytes in human decidua react with a natural-killer (NK) cell marker, NKH1. Immunology, 62, 329-331.

RITSON A., BULMER J. N., 1987b. Extraction of leucocytes from human decidua. A comparison of dispersal techniques. J. Immunol. Methods, 104, 231-236.

SEARLE R. F., 1986. Intrauterine immunization, 211-218. In CLARK D. A., CROY B. A., Reproductive immunology 1986, Elsevier Sci. Publ. B.V., Amsterdam.

SHEPPARD B. L., BONNAR J., 1981. An ultrastructural study of uteroplacental spiral arteries in hypertensive and normotensive pregnancy and fetal growth retardation. Br. J. Obstet. Gynaecol., 88, 695-705.

SLAPSYS R. M., RICHARDS C. D., CLARK D. A., 1986. Active suppression of host-versus-graft reaction in pregnant mice. VIII. The uterine decidua-associated suppressor cell is distinct from decidual NK cells. Cel/ Immunol., 99, 140-149.

STERN P. L., BERESFORD N., FRIEDMAN C. I., STEVENS V. C., RISK J. M., JOHNSON P. M., 1986. Class I-like MHC molecules expressed by baboon placental syncytiotrophoblast. $J$. Immunol., 138, 1088-1091.

STEWART I., 1984. A morphological study of granulated metrial gland cells and trophoblast cells in the labyrinthine placenta of the mouse. J. Anat., 139, 627-638. 
STEWART I., MUKHTAR D. D. Y., 1988. The killing of mouse trophoblast cells by granulated metrial gland cells in vitro. Placenta, 9, 417-425.

TAWFIK O. W., HUNT J. S., WOOD G. W., 1986. Implication of prostaglandin $\mathrm{E}_{2}$ in soluble factor-mediated immune suppression by murine decidual cells. Am. J. Reprod. Immunol. Microbiol., 12, 111-117.

TEKELIOGLU-UYSAL M., EDWARDS R. G., KISNISCI H. A., 1975. Ultrastructural relationships between decidua, trophoblast and lymphocytes at the beginning of human pregnancy. $J$. Reprod. Fert., 42, 431-438.

VON NUMERS C., 1953. On the specific granular cells (globular leucocytes) of the human endometrium. With special reference to their occurrence in different pathological conditions and to their staining properties. Acta Path. Microbiol. Scandinav., 33, 250-256.

WEILL P., 1921. Les cellules granuleuses des muqueuses intestinale et utérine. Arch. Anat. Microsc., 17, 77-82.

WYNN R. M., 1974. Ultrastructural development of the human decidua. Amer. J. Obstet. Gynecol., 118, 652-670. 